\title{
HOW TO ENJOY A TEETOTAL ALL-NIGHT PARTY: ABSTINENCE AND IDENTITY AT THE SAKHA PEOPLE'S YHYAKH
}

\author{
Eleanor Peers, Stepan Kolodeznikov
}

\begin{abstract}
This paper exploits the interconnections between alcohol use and politics, to examine changing forms of Sakha identification in the Sakha people's northeast Siberian Republic, Sakha (Yakutia). The Sakha people are an indigenous Siberian community; their territories have been under Russian administration since the early seventeenth century. The public event that is this paper's main focus - the Yhyakh - is a shamanic ritual, which has come to be regarded as a quintessential traditional Sakha practice.

Like many other non-Russian communities across the Soviet Union, the Sakha people have been experiencing a cultural revival, in the wake of an intensive attempt at cultural homogenisation during the Soviet era. Moderate Sakha nationalist politicians enjoyed a heady period of political dominance during the 1990s, which ceased with the advent of the Putin administrations. The Sakha people have since then watched the political and economic power of the Sakha nationalist movement fade into nothing, as the central government in Moscow has re-asserted its dominance over the Russian Federation's subject regions. This brief examination of alcohol consumption at the Yhyakh reveals the emergence of new conventions and discussions surrounding pleasure-seeking, physical discipline, and ethnic identification. It shows how the Sakha identification for many has become integrated into projects of personal reformation, as part of a broader acceptance of the Sakha national revival and its aims. The Yhyakh has become a fulcrum for the physical, spiritual and moral aspirations of a nationalist movement that can no longer exert a political influence, but is nonetheless capable of shaping aesthetic and moral values, and physical practice.
\end{abstract}

Keywords: alcohol use, cultural revitalisation, post-Soviet identification, Sakha culture, shamanism, Siberia

\section{INTRODUCTION}

The consumption of alcohol is a fact of everyday life in societies across the world, both past and present: the motivation to alter one's state of consciousness through drinking has been pervasive throughout the centuries, whether or not this alteration is a source of enjoyment. Intoxication and its consequences 
are one focus of human behaviour, and as such are integrated into the values and disciplines that both shape and reproduce social hierarchies, and their corresponding identifications and ontologies. Different forms of alcohol use manifest the varying experiences of the body, along with conventions related to pleasure-seeking and constraint, among the world's communities, and the social realities they inhabit. These conventions articulate belonging, in addition to the interrelations between those who can set or exploit the status quo, and those who can merely conform to it. Alcohol use therefore reflects forms of community, identification, and political relationship, as well as their interrelated values. ${ }^{1}$ This paper exploits the interconnections between alcohol use and politics, to examine changing forms of Sakha identification in the Sakha people's northeast Siberian Republic, Sakha (Yakutia). ${ }^{2}$

Life in Sakha has been marked over recent decades by the shifting fortunes of the Sakha nationalist cultural revival, which emerged in the late 1980s, along with other non-Russian nationalist movements across the Soviet Union. After more than three centuries of Russian administration, and a highly determined and effective attempt at cultural homogenisation during the Soviet period, Sakha nationalist groups called for a concerted effort to affirm and revive disappearing Sakha cultural forms, and even for a greater level of political autonomy, during the 1990s. Sakha people currently represent the largest ethnic group in the Republic, making up 49.9 per cent of the population; the capital of Sakha, Yakutsk, is now very much a Sakha city. ${ }^{3}$ Most scholars agree that they are descended from Turkic communities, who migrated northwards from southern Siberia during the second millennium. ${ }^{4}$ Shamanic relationships and practices were integrated into Sakha daily life until the Soviet era, despite Tsarist Russian efforts to Christianise Sakha populations. The public event that is this paper's main focus - the Yhyakh - is a shamanic ritual, which has come to be regarded as a quintessential traditional Sakha practice. Moderate Sakha nationalist politicians enjoyed a heady period of political dominance during the $1990 \mathrm{~s}$, which ceased with the advent of the Putin administrations. Sakha people have since then watched the political and economic power of the Sakha nationalist movement fade into nothing, as the central government in Moscow has re-asserted its dominance over the Russian Federation's subject regions.

Following the 1990s national revival, the Sakha population is keenly aware of both its cultural particularity, and the extensive natural resources within the Republic's territory, which are now being exploited by Russian corporations. The Sakha regional administration experiences a need to appease the titular population by sponsoring large Sakha cultural events, such as the Yhyakh (Peers 2010; Sántha \& Safonova 2011). The Sakha nationalist intellectuals, who have 
retained the objective of reviving the Sakha people's cultural and religious tradition, can benefit from the political establishment's desire to stage sumptuous Yhyakh festivals, while having to negotiate the political interest in reducing Sakha nationalist fervour. A foreign observer might well ask themselves what the contemporary Yhyakh really means, given the increasing similarity of Sakha ways of life to those of their Russian neighbours, and the increasing dominance of the federal government. Is it a pretty show, staged to appease aging Sakha nationalists? Could it just be another of the prominent and expensive public occasions that local administrations use to mollify regional populations across Russia? Or perhaps, as this examination of alcohol use suggests, the Yhyakh in fact manifests a consolidation of Sakha national pride, despite their Republic's lack of political clout?

As the first section of this paper will explain, the Sakha people's Yhyakh ritual has been for centuries a celebration of their community and its status quo - and, as such, is a particularly clear example of the interaction between politics, consumption, and identification. This section describes pre-Soviet Yhyakh rituals and their fate during the twentieth century. In doing so, it will illustrate the impact Russian colonisation has had on Sakha society, and the forms that relationships between pleasure-seeking and social hierarchy can take. The second section introduces the Russian Federation's post-Soviet antialcohol campaigns, and their intersection in Sakha with ethnic stereotypes associated with indigenous Siberian alcohol use. The final section examines the changing consumption of alcohol at the newly revived Yhyakh, and the qualities of Sakha identification that are emerging in tandem.

\section{POLITICS, PLEASURE, AND THE YHYAKH}

The ethnographic and historical data on pre-Soviet Sakha communities are incomplete and sometimes controversial - and yet these records consistently describe ritual feedings of spirits, called Ysyakh, or sometimes Ysoech (cf. Sieroszewski 1993; Khudyakov 1969; Lindenau 1983). ${ }^{5}$ As this section will show, the Yhyakh past and present have manifested the complex interactions of Sakha and Russian elites, and their integration into Sakha society. In particular, the different patterns of recreation and pleasure-seeking at the Yhyakh have reflected the changing configurations of power and economy, incorporating entities as various as Sakha Toyons, or princes, Russian colonialists, and the local area spirits. 
Successive Tsarist, Soviet, post-Soviet and foreign academic literatures on Sakha culture have generally taken the form of ethnography, or archaeology, and the ethnographic material produced before the Soviet period is both scanty, considering the huge size of the region, and heavily influenced by the Eurocentric perspectives of the German, Polish, or Russian investigators. As one might expect, the fragmented glimpses of Sakha life and culture we catch through this literature reveal wide regional variations on a number of common cultural elements - such as an animist worldview incorporating a pantheon of upper gods and lower demons - and a process of cultural transformation, under the influence of both Russification and interaction with other Siberian peoples, such as the Tungus. The descriptions of Yhyakh rituals also vary widely within this literature. Wacław Sieroszewski, for example, puts his descriptions of the Yhyakh festivals he witnessed during the 1880s in a chapter on kin relationships, rather than the chapter on shamanic belief and practice (Sieroszewski 1993: 445-449). He distinguishes Yhyakh rituals from shamanic practice as being "joyful and life-affirming" rather than "gloomy" (ibid.: 648), asserting that they were one of the "symbolic celebrations and rituals" that consolidated alliances between kin groups (ibid.: 445). Meanwhile Ivan Khudyakov, writing about Verkhoyansk region in the late 1860s, presents Yhyakh rituals as one of the ways Sakha communities could engage with the spirits (Khudyakov 1969). He describes Yhyakh rituals devoted both to the upper spirits, and to the demons (ibid.: 262); the latter would involve a blood sacrifice, something that now is never associated in public with the Yhyakh and its tradition.

Nonetheless, the Yhyakh always seems to have occurred as a large-scale event, whether it formed part of a yearly cycle, or was celebrating a specific happening, such as a wedding or victory. The Yhyakh seems to have explicitly involved the entire community, rather than the circle of friends and kin immediately concerned with a shamanic healing ritual, for example. This community would include the spiritual entities that inhabited the visible environment. Most accounts of Yhyakh rituals describe long recitals of prayer-poems by a ritual specialist, as he or she offered the gods and higher spirits a range of sacrifices, such as fermented milk of a mare (kymys), or white horse hair. Eighteenth and nineteenth-century ethnographers mention circle dances, called Ohuohai, during which large numbers of people would dance for hours, if not days and nights (Khudyakov 1969; Lindenau 1983; Sieroszewski 1993). The poems that accompanied the Ohuohai were seen to have been inspired by the higher spiritual entities, and would praise the generosity and munificence of the gods and spirits; Ohuohai dancers would thus be engaging with the upper spirits, through the aesthetic pleasure of the dance and its poetry (Balzer 1997; Crate 2006a; Peers 2012). 
The earlier ethnographic data indicates that the Yhyakh played an important role in affirming and reproducing Sakha communities, and their hierarchies, in addition to its spiritual purpose. Thus Jakob Lindenau writes about an Ysoech ritual in the $1740 \mathrm{~s}$, during which shamans addressed prayers to the upper gods before the attendees sought and obtained a blessing from their local Toyon, in an event that must have articulated a range of power relationships, between both human and non-human entities (Lindenau 1983: 36). Sieroszewski and Khudyakov also specify that nineteenth-century Yhyakh rituals were held by rich individuals for their community, in part to demonstrate their wealth and status (Sieroszewski 1993; Khudyakov 1969). Yhyakh festivals required a considerable outlay: goods had to be provided for sacrifice, in addition to enough expensive food and kymys to satisfy guests from the entire area; shamans had to be persuaded to preside over the main ritual; games, horse races and other entertainments also had to be organised. As the above quotation from Sieroszewski indicates, the Yhyakh rituals orientated towards the upper gods were opportunities for enjoyment and recreation. The upper gods and spirits would be praised, as further blessings were sought from them. As part of this, the attendees would enjoy their produce, and the achievements of their sportsmen, horses and artists - while finally having the chance to consume an abundance of food and drink, after the vicissitudes of winter and early spring. The sponsor of the Yhyakh would establish his status, while reinforcing community ties through the shared experience of the ritual. These events, ultimately, combined different forms of pleasure into a celebration of the contemporary order, which itself incorporated overlapping hierarchies of humans, spirits and gods (Peers 2012). Yhyakh rituals enabled their participants both to perceive and re-affirm their places within a continuous cosmological and social status quo. As such, Yhyakh rituals over the centuries have revealed changes in Sakha social differentiation, under the influence of successive Russian colonialist administrations - in addition to the shifting experiences of community and identity that emerged in tandem.

As an event distinguished by the generous consumption of food and drink, the Yhyakh has also reflected the changes in Sakha pastoralism and economic organisation, brought about by Russification. W. Sieroszewski's and A. Middendorf's late nineteenth-century interlocutors were claiming that the Yhyakh was a dying tradition; Khudyakov's informants also described their Yhyakh rituals as much less elaborate than those of the past (Sieroszewski 1993; Middendorf 1878; Khudyakov 1969). Kumys was giving way to Russian vodka and tea, as more and more Sakha communities increased their cattle herds at the expense of horses (Sieroszewski 1993; Middendorf 1878). Sakha populations in the regions around Yakutsk in particular were becoming more concentrated and 
sedentary; they had also started to grow wheat, under the Russian influence. Cows, although regarded as inferior to horses in intelligence and hardiness, were easier for a settled population to keep, while producing a larger quantity of milk and meat. Hence, Yhyakhs were becoming less common in part because fewer people were capable of providing enough kymys. Popular tastes also seem to have been changing: Sieroszewski in particular claimed that the vodka and tea tent was the focus of attention at the Yhyakh he attended, rather than the kymys container (Sieroszewski 1993: 446). The changing social and economic order was influencing the perception and pursuit of enjoyment - in this case, towards the experiences generated by drinking caffeine and strong alcohol, rather than kymys.

Soviet-era Yhyakh festivals also manifested the massive social and political transformations that took place in Sakha, as the Soviet administration pursued its aim to create a homogeneously modernist, materialist communist society. The Tsarist state's successor was to bring in its own configuration of legitimate pleasure-seeking, power relationship, and community. Although the earlier Soviet administrations discouraged and sometimes forbade Yhyakh rituals in parts of Sakha, they perceived its significance for the Sakha population to be such that an outright ban would have generated serious problems. Instead, successive Soviet propagandists attempted to harness the Yhyakh for their own purposes - for instance, replacing the ritual feeding of local gods and spirits with the presentation of kymys to a portrait of Josef Stalin (Romanova 1994: 149). Large, secularised Yhyakhs were organised all over Sakha at the end of the Second World War, to hearten and encourage the Sakha population exhausted by the war effort. As the twentieth century continued, and pan-Soviet systems of education, cultural production and economic organisation reduced the cultural particularity of Sakha populations, Yhyakh rituals either came to resemble the multifarious other Soviet state holidays, or, in some areas, disappeared entirely. Sakha people have described Yhyakh festivals that would commence with speeches from the local administration and party leaders, as did all the other Soviet holidays (cf. Lane 1981). If these Yhyakhs reflected the Soviet-era organisation of power, they also reflected Soviet-era pleasure-seeking - and, in particular, the association between relaxation and drinking alcohol. Sakha people have claimed that the Yhyakh was seen as another chance to enjoy oneself by getting drunk with one's friends, along with the other state holidays and special occasions. Vodka and cognac were consumed in much, much larger quantities than kymys, and anyone dancing the Ohuohai was, more often than not, taking part in a folk-dancing competition (Crate 2006a). Since for many people the Yhyakh had become indistinguishable from the other Soviet 
holidays, they do not seem to have attached much importance to it - with the exception of some Sakha communities living at a distance from Yakutsk, who continued to experience the Yhyakh as a particularly Sakha form of celebration and thanksgiving (Crate 2006b).

Key members of the Sakha nationalist intelligentsia staged prominent Yhyakh festivals during the late 1980s and early 1990s, as part of their campaign to reassert the worth and relevance of the Sakha heritage. Since then the Yhyakh has become one of the Republic's most important holidays. Hundreds of thousands of people now attend the Republic's largest Yhyakh, put on by the municipality of Yakutsk; every other Sakha settlement in the Republic holds its own Yhyakh, as do many of the Republic's larger institutions, private businesses, and family groups. It provides what is clearly a welcome excuse for Sakha citizens to explore their interest in their traditional culture, in shamanism, alternative medicine and spirituality, while relaxing with their families and friends. The various forms of pleasure-seeking at present-day Yhyakhs continue to manifest the Sakha people's changing cosmological and social setting, and the patterns of identification this setting generates.

As in the past, the current Yhyakh can take innumerable forms, depending on the agenda and means of its organisers. However, an Yhyakh generally includes the ritual feeding of the upper spirits and gods, followed by the Ohouhai; extensive speeches from the politicians and businessmen who are sponsoring the event; eating, drinking and relaxing with family, friends and colleagues; performances of Sakha folk and pop music and dancing; and competitions in traditional Sakha sports. The larger, state-sponsored Yhyakh festivals last for a couple of days, interspersed with a ritual greeting of the sun on one of the mornings. Yakutsk Yhyakh incorporates several sound and concert stages, food stalls, a sports area, horse racing, fashion shows, and a market selling Sakha art, crafts, clothes, jewellery, and souvenirs - in addition to areas where individuals can receive their own shamanic ritual cleansing, healing, and advice. A large part of the festival site is taken up with a series of small enclosures, in which individual organisations and regional administrations host their own rituals, exhibitions, and parties.

The present-day Yhyakh exhibits, in particular, the tensions within both Sakha identification, and the relationships between the Sakha population, their politicians, and the Russian federal government. The effects of Sakha's troubled identity politics, in addition to the increasing influence of foreign cultural products and technologies, are very apparent. Yakutsk Yhyakh is shot through with the ambiguity that surrounds the Sakha identification, whether manifested through the occasion's political communication, cultural production, shamanic 
spirituality, commerce, or individual decisions about how to enjoy the holiday. For example, the proclamations about the Yhyakh that are broadcast throughout the ritual claim on occasion that the Yhyakh is 'a holiday for all peoples' (vsenarodniy prazdnik); however, they can also remind the audience that the Yhyakh was initiated by the illustrious forefather of the Sakha people, Elley, as a great Sakha tradition. These announcements are part of the cultural establishment's effort to encourage the Sakha to respect and value their cultural tradition, which forms a dominant part of the festival's didactic purpose. And yet the Yhyakh's organisers also provide their public with wooden sculptures inspired by Korean shamanism, and Native American totem poles; contemporary Yhyakh participants can now enjoy exotic versions of their own tradition, by taking and disseminating photographs of themselves with these sculptures.

In the wake of the cultural revival, many of the Sakha people at Yakutsk Yhyakh really are there to receive spiritual cleansing, as part of engaging with their pre-Soviet shamanic tradition. They may pay particular attention to the Yhyakh's main ritual, undergo private shamanic healing ceremonies, or attend the greeting of the sun - or they may themselves be helping to administer the various forms of the Sakha shamanic ritual. These people are likely to see the Yhyakh as an occasion that enables them to engage with and articulate their deepest religious and moral convictions, and thus as one of the year's most important events. Nevertheless, a large proportion of Yhyakh attendees - likely to include many of those who appreciate the Yhyakh's spiritual aspect - are there as consumers of the various attractions provided by both state and commerce. There are market stalls to browse, for example, fairground rides for children, and an array of food and drink that includes hot dogs, ice creams, and the more traditional boiled horse-meat, served on sticks. The events of the twentieth century have shifted the Sakha population into a mass consumer society, with its corresponding forms of pleasure.

The contemporary Yhyakh therefore reflects the complexity of Sakha society, as it undergoes rapid social change. It stands at an intersection of politics, nationalism, leisure, fashion and spirituality. The following discussion of alcohol use at the Yhyakh will show how drinking has been integrated into the changing meaning of Sakha identification, and the communities this identification has shaped within Sakha. It will reveal a new potential for Sakha identification to generate forms of physical discipline and abstinence. 


\section{ALCOHOL USE, ETHNIC DIFFERENCE AND GOVERNANCE IN POST-SOVIET SAKHA}

Several acquaintances from Sakha have described the 1990s as a period when the only available pleasure and distraction from the hard work, setbacks, and uncertainty was a bottle of vodka shared with friends. As was the case all over the former Soviet Union, and, indeed, in many other societies, the assumption that a good party involves alcoholic drink could expand into the use of social drinking to cope with large-scale social upheaval. Alcohol may have been a form of release and recreation, but it was also a danger. The risk of abandoning all prospects and relationships to alcohol dependency was high, as was the possibility of being injured, sexually assaulted or killed in a drunken attack. During the early 2000s, the residents of Yakutsk would avoid being on the streets during the winter after 9 p.m., afraid of gangs of young, drunken men.

Most disturbingly, this problem was seen to be culturally specific: the offenders were pinpointed as Sakha university students, who had recently migrated to Yakutsk from exclusively Sakha villages. Longstanding citizens of Yakutsk whether Russian or Sakha - found these students provincial and bad-mannered, while the former villagers were disgusted to find that many young urban Sakha people did not appear to value their cultural heritage, to the point where they had no Sakha language. Under the influence of alcohol, these tensions could erupt into potentially deadly fights. Alcohol consumption was thus integrated into broader ambivalences within Sakha identification, arising from the differences between urban and rural status, and the intersecting influences of Soviet and post-Soviet cultural homogenisation, with the late Soviet cultural revival. Urban Sakha populations tended to be more closely assimilated into Russia's wider hierarchies, and therefore also mainstream Russian conventions of thought, behaviour, and language (Argounova-Low 2007). The presence of a large, rural Sakha-speaking population, in conjunction with the national revival, brought into question individual loyalties to the Sakha community, and its prosperity. On the other hand, Tsarist and Soviet-era stereotypes about 'primitive', 'uncivilised' indigenous Siberian populations and their inability to manage alcohol combined with the higher, more 'civilised' status of urban Sakha people, and their repugnance at the sometimes violent drunkenness of village students, to create a rift that exacerbated a broader concern about the worth of Sakha culture and heritage.

Government administrations at all levels throughout the Russian Federation were making efforts to discourage drinking during the 2000 s, and are continuing to do so. This promotion of teetotalism conforms to Vladimir Putin's public image 
as a fit, ascetic, disciplined man, in contrast to the chaotic Boris Yeltsin. To an extent, it is addressing a significant social issue; however, it can also be seen as a method of establishing the government's legitimacy. Local administrations across Russia can show themselves to be energetically solving problems, for the relatively low cost of some prominent anti-alcohol advertisements in public spaces and the mass media. ${ }^{6}$ Noticeably, these advertisements tend to cite alcohol use as a dysfunctional behaviour that needs to be eliminated, rather than the underlying social and psychological problems that cause excessive drinking.

The anti-alcohol campaigns in Sakha have been spiced by the worry about an innate inability to handle alcohol on the part of indigenous Siberians, mentioned above. The need to prevent alcohol consumption is now perceived to be strong enough to merit the limitation of alcohol sales in Yakutsk to between 2 p.m. and 8 p.m.; this measure was introduced in 2011. Some rural settlements have had a complete prohibition on alcohol sales. This innate incapacity to drink is now widely conceived of as a genetic deficiency. Many people contend that the European peoples have developed a gene that helps them to manage alcohol, along with their brewing and wine-making traditions. This gene, they argue, is absent in North Asia, since northern indigenous communities, like First Nation societies in North America, have never produced alcoholic drinks. However, Jaanus Harro in his keynote speech at a workshop in 2013 stated that there is as yet no evidence that European people have a gene that helps them digest alcohol, so that they do not become as drunk - only that there is a higher incidence in Asia of a gene that exacerbates the nausea experienced during a hangover (see Harro 2013). Several Asian peoples have developed their own alcoholic drinks - such as the Mongolian milk liqueur, arkhi. Indeed, some Sakha consultants are aware of the possibility that earlier Sakha populations also produced significantly alcoholic fermented milk drinks, in common with other Turkic peoples: present-day kymys does contain a very small percentage of alcohol, enough to make one light-headed for a couple of minutes after drinking a cup.

In fact, a questionnaire by Tatiana Argounova-Low and Yuri Zhegusov has indicated that ethnic Sakha people tend to drink less than Russians (ArgounovaLow \& Zhegusov 2013). These research findings corroborate the alcohol use we have observed: if anything, alcohol use is less a part of everyday life among Sakha communities than it is within mainstream Russian society. In contrast to many Europeans, including Russians, most Sakha people do not assume that welcoming a guest involves offering them alcohol. Consuming a small amount of alcohol at meals on a regular basis, with or without company, is much more likely to be regarded as worrying and abnormal behaviour, rather than as just 
another personal habit. The majority of Sakha people at the many social occasions we have attended have enjoyed their drinks, without becoming excessively drunk. That said, we have occasionally witnessed Sakha people drinking a large amount of alcohol disturbingly quickly, before disrupting the occasion with behaviour that was often, ultimately, self-destructive. These incidents show why many people in Sakha might be afraid of alcohol consumption. However, the similar exhibitions of excessive drinking we have seen in other parts of Russia lead us to wonder whether the problem can be better understood in terms of a particular legacy of alcohol abuse common to the former Soviet space, rather than an innate and ethnic-specific incapacity to handle alcohol. Whatever the truth may be, a worry about an inherently Sakha capacity to misuse alcohol remains widespread, while the wholesale condemnation of alcohol use continues to be prominent in official discourse throughout Russia.

\section{DRINKING AND ABSTINENCE AT THE MODERN-DAY YHYAKH}

The consumption of alcohol at post-Soviet Yhyakh festivals has reflected the changing incorporation of alcohol use into recreation, survival and governance in the broader Russian Federation; however, recently Sakha nationalist activists have added their own spin to the state-sponsored anti-alcohol campaigns that have been occurring throughout Russia, as we will explain below.

In 2011 and 2012, the engineers of the Sakha cultural and spiritual revival described the Yhyakh festivals of the 1990s and early 2000s as much more 'Soviet' and 'theatrical' (teatrilizovannye) than the most recent Yhyakhs. These festivals were organised and choreographed by cultural workers who had been trained during the Soviet era, and therefore reflected theatrical and aesthetic conventions ubiquitous throughout the Soviet Union (Donohoe \& Habeck 2011). These events were presented to the Sakha population as a revival of their heritage. This population was already having to manage the legacy of the Tsarist and Soviet-era disparagement or repression of many indigenous Siberian cultural practices, and their own alienation from the practices and worldviews of their forbears - in addition to the economic hardships and social crises of the 1990s.

Unsurprisingly therefore, popular reactions to the Yhyakh revival were mixed; people could come to the Yhyakh to take advantage of some free entertainment, rather than to engage with their spiritual heritage. As part of this, they could view the Yhyakh as an excuse for a drink, as many had done during the Soviet era. Some of the people who were bringing alcoholic drinks to the ritual may only have been continuing the older practice of feeding vodka to the 
area spirits, as part of a celebration of local human and non-human relationships. However, by all accounts, the alcohol consumption at Yakutsk Yhyakh in particular became a serious problem during the early 2000s. Several friends and acquaintances have told us that they stopped going to the Yhyakh rituals during the mid-2000s, because they were afraid of the drunkenness they would encounter there. The destructive binge-drinking that haunted Sakha had found its way into the Yhyakh, and was making a mockery of the Sakha intelligentsia's commitment to the revival of shamanic spirituality, and traditional cultural production.

The consumption of alcohol at Yakutsk Yhyakh was banned in 2007. It is currently forbidden to bring alcoholic drink onto the festival site, or sell it; policemen check the belongings of people entering the festival during the night. Many Sakha people have commended this ban to us, sometimes also explaining that Sakha people, unlike Europeans, are unable to manage alcohol. Most people prefer not to elaborate on this point; however, a few conversations have indicated that this inability to manage alcohol refers to a propensity to become intoxicated beyond all self-control, unleashing one's potential for both violent aggression and self-humiliation.

The persisting assumption that Sakha people are inherently unable to drink in moderation is perhaps one reason why Sakha nationalist intellectuals and activists are keen to discourage alcohol consumption within Sakha communities. Many of these individuals form a recognisable network within Sakha political, academic and artistic establishments; as we have mentioned, nationalist activists and politicians have an interest in co-operating with each other, even if their fundamental objectives may be very different. Nationalist activists therefore are under an imperative to echo the political anti-alcohol campaigns, in order to maintain their public respectability. And yet prominent Sakha intellectuals do not merely emphasise the negative consequences of alcohol use: many also assert that those who are truly committed to their Sakha heritage respect the teetotal lives of their forefathers, by abstaining from alcohol. This contention undermines the degrading implications within the allegation that Sakha people cannot drink, by re-positioning the colonising Russians as the corrupting influence that introduced alcohol to pre-colonial Sakha communities. An inability to drink in moderation here becomes the mark of a heritage unsullied by a tradition in alcohol production, rather than a manifestation of indigenous backwardness: while the Russian vodka traders are sometimes equated with the white settlers who brought alcohol to Native American populations, with devastating effect. This line of argument emphasises the Sakha people's status as a north Asian indigenous community - at the expense of the Turkic aspect 
of their heritage, which, as we have mentioned, implies the possibility that earlier Sakha populations made fermented milk drinks.

Teetotalism has become a prominent part of the lives of some Sakha patriots, to the extent that alcohol sometimes is no longer offered at the formal banquets that take place during regional Yhyakh festivals. This is a very recent change: alcohol was served at the Yhyakh banquet in Khangalass region in 2009; however, an equivalent banquet in 2012 was accompanied only by tea, cowberry juice (mors, in Russian), and kymys. These banquets are generally hosted by the region's local administration, for the Yhyakh's most notable guests - whether they are eminent businessmen, politicians, intellectuals, cultural workers, or foreign academics. This selection of guests generally includes people who are explicitly concerned with reviving the Sakha heritage. The connections between Sakha nationalist networks and the political elites are close enough for even Russian politicians to moderate their behaviour to suit Sakha nationalist sympathies, particularly at what is emphatically a Sakha national event: we have seen ethnic Russian politicians wear Sakha national costumes, for example. Of course, Russia's elites cannot expect to get away with getting blind drunk at a formal banquet, especially given the official disparagement of alcohol consumption that has been a feature of the Putin administrations. However, a complete absence of alcohol at what is after all a closed event is striking, forestalling as it does the possibility of toasting with alcohol, generally an integral part of celebration in Russia. This change in practice accords with the emphatically teetotal stance prominent Sakha revivalist activists and shamanic practitioners have taken in recent years, and indicates that an avowed repugnance towards alcohol consumption has become a sufficiently powerful norm among Sakha elites to pressure the political establishment into adopting it themselves.

Moreover, the extent to which this norm is shaping conventionally respectable behaviour and values manifests a new quality of Sakha identification. The belief that someone who is genuinely and laudably committed to revitalising Sakha culture eschews alcohol assumes the Sakha identification to entail a conscious aspiration towards self-improvement, which incorporates physical discipline. The Sakha cultural revival therefore is understood to impose criteria for the physical and moral characteristics of those who espouse it as a worthwhile project. Instead of being a potentially embarrassing label for the members of a Siberian indigenous community, the Sakha identification has become for some a quest to change their lives and bodies for the better. These are the people who regard the Yhyakh as a crucial opportunity for spiritual cleansing, and the celebration of their most essential values. Their revived enthusiasm for the pre-Soviet shamanic universe, combined with the effects of 
post-Soviet political and social change, has transformed the values associated with pleasure-seeking and community affirmation. Alcohol consumption is now seen as a hindrance to a harmonious relationship with Sakha ancestors, and their deities - and hence as profoundly destructive, rather than a pleasurable social pastime. Small wonder, then, that the organisers of Yakutsk Yhyakh do their best to prevent degrading exhibitions of drunkenness, even if they have to forego the revenue that could be generated from allowing beer stalls.

The Sakha revival is still a work in progress - as is the process of selfimprovement many of its proponents have undertaken. There may be several highly disciplined and committed Sakha revivalists who are teetotal, and especially at the Yhyakh; however, there were other individuals at Yakutsk Yhyakh in 2011 and 2012 who successfully smuggled in bottles to have with their picnics. It is still possible to catch sight of a happy family party, sometimes in Sakha national costumes, unobtrusively pouring wine into their plastic cups. The legacy of Soviet-era recreational drinking and the continued presence of mainstream Russian alcohol advertising mean that many are drawn to celebrate their holiday with a drink. These people may only be continuing the centuries-old Sakha practice of self-indulgent consumption at the Yhyakh; however, nowadays they might also be seen to be compromising their status as genuine Sakha patriots.

And yet these individuals, and the people around them, are happy to accept the tensions within displaying one's Sakha national pride by participating in the Yhyakh, perhaps even in national costumes, while consuming European wine or cognac. This acceptance parallels the silent acknowledgement of the cooperation of Sakha intellectuals with politicians and businessmen who do not have the interests of the national revival at heart. Sakha communities and their histories continue to be integrated into broader Russian, and even global, political economies, which continue to shape both national and religious revival, and popular recreation. Like other national revivals around the world, the claim of Sakha revival towards having an authentically Sakha authorship, aim and effect is extremely complex (cf. Asad 1993).

The paradoxes within Sakha alcohol consumption show that the national revival has consolidated itself into consistent categories of identification, value, and aspiration, which are recognised and acknowledged by a large proportion of the Sakha community. Sakha people can now adopt a spectrum of characteristics - including recognisable forms of physical discipline - into their aspirations for their own personal development, and this process of self-development is proudly and self-consciously Sakha. This affirmation of a Sakha identification is paralleled by a loyalty towards the Sakha people as a distinct community 
within the Russian Federation, demonstrated by the willingness to disregard the moments when individuals or groups fail to live up to the ideal. The inhabitants of Yakutsk now say that the problems they experienced with drunken Sakha students have abated over recent years: the drunk and violent have migrated to certain troubled areas on the outskirts of Yakutsk, leaving the respectable Sakha mainstream to get on with its business. As the fractures engendered by cultural difference and insecurity have decreased, making irrelevant the previous rift between urbanised and rural Sakha, the Sakha community can now recognise its validity, worth, and common aims. Many Sakha people also recognise an increasing urgency about the need to preserve and promote Sakha culture and heritage, in the face of increasing immigration from China and Central Asia, and the dominance of the overtly pro-Russian federal administration.

\section{CONCLUSION}

As the Sakha case shows, alcohol use is embedded into the nexus of value and practice that spans politics, and the everyday treatment of the body. It can thus manifest the deeper shifts in aesthetic and moral value, motivation, and identification, which accompany a changing political landscape. This brief examination of alcohol use at the Yhyakh has revealed that the Sakha identification for many has become integrated into projects of personal reformation, as part of a broader acceptance of the Sakha national revival and its aims. Far from being an expensive show to mollify and entertain, the Yhyakh has become a fulcrum for the physical, spiritual and moral aspirations of a nationalist movement that can no longer exert a political influence, but is nonetheless capable of shaping aesthetic and moral values, as well as physical practice. 


\section{NOTES}

1 The intersection between physical discipline and power has been a topic of scholarly discussion for many decades, most prominently in the wake of Michel Foucault's life and work.

2 One of the authors is British; she has been visiting Sakha since 2004, and has been gathering data on the Yhyakh since 2009. The other author is Sakha, and has spent most of his life in Yakutsk, witnessing the events and transformations described here at first hand. Our contentions here are based on the British author's observations, the Sakha author's life experience, and the interchange of our two perspectives as we developed the piece.

3 See http://www.perepis-2010.ru/results_of_the_census/, last accessed on April 22, 2015.

4 See, for example, Crate 2006b; Maak 1994 [1887]; Gogolev 2004; and Jochelson 1933.

5 S often becomes h in contemporary Sakha language, and hence our Sakha interlocutors tend to speak about the Yhyakh, sometimes asserting that Ysyakh is a Russianised pronunciation of the word. We follow the contemporary Sakha usage in calling this event Yhyakh.

6 A body of literature has been developing on the expansion of governance through positing problems. See, for example, Ssorin-Chaikov 2003, and Gupta 1995.

\section{REFERENCES}

Argounova-Low, Tatiana 2007. Close Relatives and Outsiders: Village People in the City of Yakutsk, Siberia. Arctic Anthropology, Vol. 44, No. 1, pp. 51-61. http:// dx.doi.org/10.1353/arc.2011.0072.

Argounova-Low, Tatiana \& Zhegusov, Yurii 2013. Coded: Perception and Treatment of Alcohol Addiction in Sakha (Yakutiia). "Drinking and driving is so much fun": Arctic workshop of the University of Tartu, May 31-June 1. Conference paper.

Asad, Talal 1993. Genealogies of Religion: Discipline and Reasons of Power in Christianity and Islam. Baltimore \& London: The Johns Hopkins University Press.

Balzer, Marjorie Mandelstam 1997. The Poetry of Sakha (Siberian Yakut) Shamanism. In: J. Leavitt (ed.) Poetry and Prophecy: The Anthropology of Inspiration. Ann Arbour: University of Michigan Press, pp. 93-128.

Crate, Susan A. 2006a. Ohuokhai: Sakhas' Unique Integration of Social Meaning and Movement. Journal of American Folklore, Vol. 119, No. 472, pp. 161-183. http:// dx.doi.org/10.1353/jaf.2006.0019.

Crate, Susan A. 2006b. Cows, Kin and Globalization: An Ethnography of Sustainability. Plymouth: AltaMira Press. 
Donahoe, Brian \& Habeck, Joachim Otto (eds.) 2011. Reconstructing the House of Culture: Community, Self and the Makings of Culture in Russia and Beyond. New York \& Oxford: Berghahn.

Gogolev 2004 = Gogolev, Anatolii. Etnicheskaia istoriia narodov Iakutii. [The Ethnic History of the Peoples of Yakutia.] Iakutsk: Izdatelstvo IaGU.

Gupta, Akhil 1995. Blurred Boundaries: The Discourse of Corruption, the Culture of Politics, and the Imagined State. American Ethnologist, Vol. 22, No. 2, pp. 375-402.

Harro, Jaanus 2013. Alcohol and the Brain ... and Driving. "Drinking and driving is so much fun": Arctic workshop of the University of Tartu, May 31-June 1. Conference keynote speech.

Jochelson, Waldemar 1933. The Yakut. Anthropological Papers of the American Museum of Natural History, Vol. 33, No. 2. New York: The American Museum of Natural History. Available at http://digitallibrary.amnh.org/dspace/handle/2246/138, last accessed on April 23, 2015.

Khudyakov 1969 = Khudiakov, Ivan. Kratkoe opisanie Verkhoianskogo okruga. Edited by V. Bazanov. Leningrad: Nauka.

Lane, Christel 1981. The Rites of Rulers: Ritual in an Industrial Society - the Soviet Case. Cambridge: Cambridge University Press.

Lindenau 1983 = Lindenau, Iakob. Opisanie narodov Sibiri (pervaia pol. XVIII v.): Istoriko-etnograficheskie materialy o narodakh Sibiri i Severo-Vostoka. [A Description of the Peoples of Siberia (First Half of the 18th Century): Ethnographic Material about the Peoples of Siberia and the North East.] Magadan: Magadanskoe kn. izd-vo. Available at https://cloud.mail.ru/public/0707efe6851a/15.02.13, last accessed on April 23, 2015.

Maak, Richard 1994 [1887]. Viliuiskii Okrug. [Vilyui Region.] Second edition. Moskva: Iana.

Middendorf, Aleksandr 1878. Puteshchestvie na sever i vostok Sibiri. [A Journey to the North and East of Siberia.] Sankt-Peterburg: Tipografiia Imperatorskoi Akademii Nauk. Available at http://books.e-heritage.ru/book/10070614, last accessed on May 25, 2015.

Peers, Eleanor 2010. Print, Power and Personhood: Newspapers and Ethnic Identity in East Siberia. $\mathrm{PhD}$ thesis. University of Cambridge.

Peers, Eleanor 2012. Populiarnaia kul'tura, poeziia i bogi: izmeniaiushcheesia vzaimodeistvie landshafta, krasoty i dukhovnosti v iakutskom obshchestve. [Pop Culture, Poetry and the Gods: The Changing Interaction of Landscape, Beauty and Spirituality in Sakha Society.] In: N. Pavlova (ed.) Priroda i kul'tura: Materialy mezhdunarodnoi konferentsii (Iakutsk 13-15 iiunia 2012 g.). [Nature and Culture: Materials of an International Academic Conference (Yakutsk, 13-15 June 2012).] Iakutsk: Izdatel'skii dom SVFU, pp. 70-74.

Romanova, Ekaterina 1994. Iakutskii prazdnik Ysyakh: Istoki i predstavleniia. [The Yakut Ysyakh Holiday: Sources and Understandings.] Novosibirsk: Nauka.

Sántha, István \& Safonova, Tatiana 2011. Pokazukha in the House of Culture: The Pattern of Behavior in Kurumkan, Eastern Buriatiia. In: Brian Donohoe \& Joachim 
Otto Habeck (eds.) Reconstructing the House of Culture: Community, Self and the Makings of Culture in Russia and Beyond. New York: Berghahn, pp. 75-96. Sieroszewski 1993 = Seroshevskii, Vatslav. Iakuty: Opyt etnograficheskogo issledovaniia. [Yakuts: The Experience of Ethnographic Research.] Moskva: ROSSPEN.

Ssorin-Chaikov, Nikolai 2003. A Social Life of the State in Subarctic Siberia. Stanford: Stanford University Press. 